\title{
Adaptabilitas Varietas Inpara di Lahan Rawa Pasang Surut Tipe Luapan Air B pada Musim Kemarau
}

\author{
Adaptability of Inpara Varieties In Tidal Swamp Lands with Type B Overflow on Dry Season
}

\author{
Koesrini*, Muhammad Saleh, dan Siti Nurzakiah \\ Balai Penelitian Pertanian Lahan Rawa \\ Jl. Kebun Karet, PO Box 31, Loktabat Utara Banjarbaru, Indonesia
}

Diterima 10 Oktober 2016/Disetujui 7 Maret 2017

\begin{abstract}
Tidal swamp lands are marginal lands with considerable potentials for rice farming. The key solution to overcome swampy lands constraints are nutrient and water managements as well as the use of adaptive rice varieties. Inpara (inbred swampy land rices) varieties have been released by the Indonesian Agency for Agricultural Research and Development (IAARD) which are adaptive to swampy land conditions. The purpose of this research was to evaluate the adaptability of Inpara varieties in tidal swamp lands with type B overflow. The field experiment was carried out in Karang Bunga village, Barito Kuala District, South Kalimantan Province, in the dry season from April to August 2016. The research was arranged in randomized complete block design, with 3 replicates. The varieties tested, i.e., Inpara 1, 2, 3, 4, 5, 6, 7, 8, 9, and check varieties Margasari, Ciherang, and Mekongga. The results showed that the adaptability varied among varieties tested. Inpara 3, 4, 6, 8, and 9 had high yield and good adaptation on tidal swamp land yielded 3.475-4.299 ton ha'-1. These varieties produced between 38.5 to 71.3\% higher than Margasari and 51.4 to 87.2\% higher than Mekongga. Inpara 3, 4, 6, 8, and 9 could be used as a main varieties in the tidal swamp lands.
\end{abstract}

Keywords: rice, swampy land, variety

\section{ABSTRAK}

Lahan rawa pasang surut (LRPS) merupakan lahan marjinal yang memiliki potensi cukup besar untuk pengembangan padi. Kunci utama untuk mengatasi masalah di lahan tersebut melalui pengelolaan hara, air, serta penggunaan varietas padi yang adaptif. Inpara (Inbrida padi rawa) adalah varietas yang dilepas oleh Badan Penelitian dan Pengembangan Pertanian (Balitbangtan) yang adaptif di lahan rawa. Tujuan penelitian adalah untuk mengevaluasi adaptasi dan kesesuaian varietas Inpara di LRPS dengan tipe luapan air B. Percobaan lapang dilakukan di Desa Karang Bunga, Kabupaten Barito Kuala, Provinsi Kalimantan Selatan, pada musim kemarau dari bulan April sanpai Agustus 2016. Percobaan menggunakan Rancangan Acak Kelompok, dengan 3 ulangan. Varietas yang diuji adalah Inpara 1, 2, 3, 4, 5, 6, 7, 8, 9, dan varietas pembanding Ciherang, Margasari, dan Mekongga. Hasil penelitian menunjukkan bahwa ada variasi adaptasi diantara varietas yang diuji. Varietas Inpara 3, 4, 6, 8, dan 9 memiliki hasil yang cukup tinggi dan adaptif di LRPS, dengan hasil antara 3.475-4.299 ton ha . $^{-1}$ Hasil gabah kelima varietas tersebut 38.5-71.3\% lebih tinggi dibandingkan varietas Margasari dan 51.4-87.2\% lebih tinggi dibandingkan varietas Mekongga. Implikasi hasil penelitian ini adalah bahwa varietas Inpara 3, 4, 6, 8, dan 9 dapat digunakan sebagai varietas utama di LRPS.

Kata kunci: lahan rawa, padi, varietas

\section{PENDAHULUAN}

Padi merupakan salah satu komoditas strategis yang perlu terus ditingkatkan produksinya untuk memenuhi kebutuhan pangan penduduk Indonesia yang pada tahun 2017 diperkirakan telah mencapai lebih dari 255 juta jiwa. Lahan rawa pasang surut (LRPS) merupakan lahan marjinal yang potensial untuk pengembangan tanaman padi. Luas

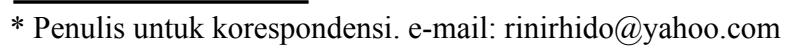

LRPS di Indonesia diperkirakan terdapat 20.1 juta ha, dari luasan tersebut 9.5 juta ha berpotensi untuk dijadikan lahan pertanian dan yang sudah direklamasi sekitar 2.27 juta ha (Nursyamsi dan Noor, 2014).

Pengembangan padi di LRPS memerlukan varietas yang adaptif terhadap cekaman lingkungan terutama kemasaman tanah, keracunan besi dan cekaman air. Masalah tersebut menjadi faktor pembatas pengembangan padi di LRPS. Majerus et al. (2007) melaporkan bahwa keracunan besi dapat menurunan hasil padi antara 30-60\%. Perbedaan penurunan hasil antara varietas toleran dan peka terhadap 
keracunan besi, seperti dilaporkan oleh Virmani (1977). Penurunan hasil akibat keracunan besi pada varietas peka dapat mencapai $75 \%$ dan varietas toleran 30\%. Audebert dan Sahrawat (2000) melaporkan bahwa kultivar padi yang toleran keracunan besi mengabsorbsi atau mentranslokasi besi dari akar ke daun lebih rendah dibandingkan kultivar yang peka dengan mekanisme ketahanan avoidance. Oleh karena itu penggunaan varietas yang toleran/adaptif terhadap kondisi biofisik lahan dan sesuai preferensi petani menjadi syarat mutlak untuk penanaman padi di LRPS. Badan Penelitian dan Pengembangan Pertanian telah menghasilkan varietas padi adaptif untuk LRPS.

Inpara (Inbrida padi rawa) adalah varietas yang dilepas untuk lahan rawa. Ada sembilan varietas Inpara yang telah dilepas, yaitu Inpara 1, 2, 3, 4, 5, 6, 7, 8, dan 9 (BB Padi, 2014). Pada saat ini varietas Inpara 2 dan Inpara 3 cukup berkembang di LRPS di Kabupaten Barito Kuala. Varietas ini memiliki adaptasi luas dapat ditanam pada beberapa agroekosistem, baik di LRPS, lebak, irigasi semi teknis dan tadah hujan. Daya hasil varietas Inpara 2 dan Inpara 3 relatif stabil antara 4.12-6.20 ton ha ${ }^{-1}$ (Kustianto, 2009; Adri dan Yardha, 2014). Varietas Inpara 2 dan Inpara 3 mulai berkembang di Kabupaten Barito Kuala sejak tahun 2012. Terjadi peningkatan luas tanam varietas Inpara yang cukup nyata dari 86 ha pada tahun 2011 menjadi 2,418 ha pada tahun 2014 (Rina dan Koesrini, 2016). Dampak positif dari pengembangan varietas Inpara di kabupaten tersebut adalah turut mendukung peningkatan produksi padi, tetapi mulai timbul permasalahan baru, yaitu adanya penanaman varietas yang sama secara terus menerus dalam 4-5 tahun terakhir ini, menimbulkan kerentanan terhadap penyakit. Varietas Inpara 2 dan Inpara 3 yang semula rendah serangan hama penyakitnya, saat ini mulai rentan terutama terhadap penyakit blas dan hama penggerek batang. Oleh karena itu perlu mulai diintroduksikan varietas Inpara yang baru, yang nantinya dapat dijadikan varietas alternatif selain varietas Inpara 2 dan Inpara 3.

Penelitian bertujuan untuk mengevaluasi daya adaptabilitas varietas Inpara 1 sampai 9 di LRPS tipe luapan air B.

\section{BAHAN DAN METODE}

Penelitian ini dilaksanakan di LRPS dengan tipe luapan air B di Desa Karang Bunga, Kecamatan Mandasana, Kabupaten Barito Kuala, Provinsi Kalimantan Selatan, pada musim kemarau (MK) bulan April sampai Agustus 2016. Pengaturan air ke dalam petakan dilakukan secara alami sesuai dengan pasang surutnya air sungai dan disesuaikan dengan kebutuhan air tanaman. Perlakuan disusun berdasarkan Rancangan Acak Kelompok dengan tiga ulangan. Varietas yang diuji adalah Inpara 1, 2, 3, 4, $5,6,7,8,9$, dan varietas pembanding Ciherang, Margasari, dan Mekongga.

Penyiapan lahan dilakukan secara mekanis menggunakan traktor. Dolomit diaplikasikan sebagai amelioran dengan dosis 1 ton $\mathrm{ha}^{-1}$ secara merata pada areal percobaan, bersamaan dengan saat penyiapan lahan. Persemaian dengan cara semai sistem basah. Bibit siap tanam umur 25 hari setelah semai (HSS). Setiap varietas ditanam pada petak berukuran $4 \mathrm{~m}$ x $10 \mathrm{~m}$ dengan sistim tanam jajar legowo 2:1 (40x25x12.5) cm, sehingga populasi tanaman adalah 960 rumpun per petak. Pemupukan pertama dengan $50 \mathrm{~kg}$ Urea $+250 \mathrm{~kg}$ Phonska per hektar pada 7 HST dan pemupukan kedua dan ketiga masing-masing $150 \mathrm{~kg}$ Phonska per hektar pada $30 \mathrm{HST}$ dan $60 \mathrm{HST}$. Pengendalian HPT disesuaikan dengan intensitas serangan. Panen dilakukan saat 90\% gabah telah matang dan berwarna kuning rata. Panen dilakukan terhadap 10 tanaman contoh dan panen petak.

Peubah yang diamati meliputi (1) analisis sifat fisik (tekstur) dan sifat kimia tanah $\left(\mathrm{pH} \mathrm{H}_{2} \mathrm{O}, \mathrm{C}\right.$-organik, N-total, P-Bray 1, $\mathrm{Ca}_{\mathrm{dd}}, \mathrm{Mg}_{\mathrm{dd}}, \mathrm{K}_{\mathrm{dd}}, \mathrm{Na}_{\mathrm{dd}}, \mathrm{Al}_{\mathrm{dd}}, \mathrm{KTK}, \mathrm{Fe}^{2+}$ ) pada saat sebelum percobaan, (2) skor pertumbuhan saat fase vegetatif dan generatif, (3) skor keracunan besi saat fase vegetatif (30 HST) dan generatif (60 HST), (4) pertumbuhan tanaman meliputi tinggi tanaman dan jumlah anakan saat fase vegetatif (30 HST), fase generatif (60 HST) dan panen, (5) hasil gabah dan (6) umur panen. Standar untuk pengamatan skor pertumbuhan dan keracunan besi berdasarkan IRRI (2014). Skor pertumbuhan, yaitu skor $1=$ tanaman tumbuh sangat vigor, skor $3=$ tanaman tumbuh vigor, skor $5=$ tanaman tumbuh normal, skor $7=$ tanaman tumbuh lemah, sebagian kerdil, populasi sedikit, dan anakan tidak terbentuk, skor 9 = tanaman tumbuh sangat lemah, kerdil, dan daun kekuningan. Skor keracunan besi, yaitu skor $0=$ tanaman tumbuh normal, tidak terlihat gejala keracunan besi, skor $1=$ tanaman tumbuh normal, ada spot coklat kemerahan atau oranye, skor $3=$ tanaman tumbuh agak normal, daun tua berwarna coklat kemerahan, ungu atau kuning oranye, skor $5=$ pertumbuhan dan pembentukan anakan terhambat, daun berwarna coklat kemerahan, skor $7=$ pertumbuhan dan pembentukan anakan sangat terhambat, sebagian besar tanaman mati, skor $9=$ hampir semua tanaman mati.

Analisis data untuk data skor, pertumbuhan, dan hasil ditabulasi, kemudian dianalisis dengan analisis varian (ANOVA) menggunakan program SAS dan dilanjutkan dengan uji Duncan Multiple Range Test (DMRT).

\section{HASIL DAN PEMBAHASAN}

\section{Kondisi Iklim}

Curah hujan rata-rata selama penelitian berlangsung $190.0 \mathrm{~mm}$ per bulan, hari hujan 15.3 hari per bulan, suhu minimum $22.2{ }^{\circ} \mathrm{C}$, suhu maksimum $34.3{ }^{\circ} \mathrm{C}$ dan kelembaban udara 82.5\%. (Stasiun Klimatologi Banjarbaru, 2016 dan Balittra, 2016). Hal ini menunjukkan bahwa kondisi lingkungan pengujian cukup sesuai untuk pertumbuhan tanaman padi.

\section{Karakteristik Tanah}

Tanah di lokasi pengujian tergolong tanah sulfat masam potensial (Sulfaquent) atau tanah aluvial bersulfida sangat dalam (SMP-3) dengan kriteria kedalaman lapisan sulfida $>100 \mathrm{~cm}$ dan $\mathrm{pH}$ tanah $>4.5$. Tipe luapan air tergolong tipe $\mathrm{B}$, yaitu lahan yang hanya mendapat luapan 
air saat pasang besar dan tidak terluapi oleh pasang kecil. Hasil analisis tanah awal (Tabel 1) menunjukkan bahwa tingkat kemasaman tanah tergolong masam $(\mathrm{pH}$ 4.62) dengan kandungan $\mathrm{C}$-organik sangat tinggi dan $\mathrm{N}$ total sedang. Ketersediaan fosfat sedang, yaitu $10.83 \mathrm{ppm}$ $\mathrm{P}$, karena diikat oleh besi atau aluminium dalam bentuk besi fosfat atau aluminium fosfat. Kandungan $\mathrm{Ca}_{\mathrm{dd}}$ sangat rendah, $\mathrm{K}_{\mathrm{dd}}$ dan $\mathrm{Na}_{\mathrm{dd}}$ rendah serta $\mathrm{Mg}_{\mathrm{dd}}$ sedang. Rendahnya kandungan $\mathrm{Ca}_{\mathrm{dd}}, \mathrm{K}_{\mathrm{dd}}$, dan $\mathrm{Na}_{\mathrm{dd}}$, terjadi karena hilang melalui proses pencucian. Rendahnya kandungan basa-basa ini menunjukkan rendahnya ketersediaan hara tersebut di dalam tanah.

Hasil analisis tanah awal menunjukkan bahwa tingkat kesuburan tanah di lokasi pengujian tergolong rendah dengan kandungan besi tinggi dan tekstur tanah liat (70.76\%): debu (26.02\%): dan pasir (3.23\%). Aplikasi kapur saat pengolahan tanah dengan dosis 1.0 ton ha ${ }^{-1}$ memperbaiki sifat kimia tanah, dengan terjadinya perubahan $\mathrm{pH}$ meningkat dari 4.62 menjadi 4.9 dan kelarutan besi menurun dari 439.56 ppm menjadi 169.07 ppm. Dolomit merupakan salah satu amelioran yang cukup banyak digunakan untuk mengatasi kemasaman tanah dan keracunan besi di LRPS. Selain ameliorasi, keracunan besi dapat diatasi dengan pengaturan air dan pengolahan tanah, seperti dilaporkan oleh Isdijanto et al. (2015). Kombinasi pengaturan air dengan proses pelindian dan olah tanah dapat menurunkan keracunan besi dan meningkatkan hasil padi di LRPS.

\section{Pertumbuhan dan Hasil}

Inpara merupakan varietas yang dilepas untuk lahan rawa baik LRPS maupun lahan rawa lebak. Informasi adaptasi varietas Inpara 1 sampai Inpara 5 pernah dilakukan oleh Koesrini et al. (2013). Hasil penelitian tersebut menunjukkan bahwa adaptasi varietas Inpara 1, 2, 3, dan 4 lebih baik daripada adaptasi varietas Inpara 5 di LRPS. Varietas Inpara 5 rentan terhadap penyakit blas yang disebabkan jamur patogen Pyricularia grisae serta tidak tahan terhadap keracunan besi.
Hasil observasi terhadap pertumbuhan sembilan varietas Inpara di lokasi pengujian menunjukkan bahwa pada kisaran $\mathrm{pH}>4.5$, tanaman padi sudah dapat tumbuh dan berproduksi baik berdasarkan nilai skor pertumbuhan antara 2.3-3.0, yaitu tanaman tumbuh dengan vigor baik. Analisis ragam terhadap skor pertumbuhan saat fase vegetatif tidak menunjukkan perbedaan, sedangkan saat fase generatif berbeda nyata (Tabel 2). Skoring pertumbuhan varietas Inpara 1 sampai 9 rata-rata sama dengan ketiga varietas pembanding dengan skor pertumbuhan antara 1.7-3.0, yaitu tanaman tumbuh dengan vigor baik sampai sangat baik. Skor pertumbuhan varietas Inpara 4 lebih baik dibandingkan skor pertumbuhan varietas Inpara 5. Varietas Inpara 4 dan 5 adalah hasil introduksi dari IRRI. Varietas Inpara 4 berasal dari galur Swarna-Sub 1 (IR05F101) dan varietas Inpara 5 berasal dari galur IR 64 sub 1 (IR07F102) (Debrata dan Sarker, 2012; Hairmansis et al., 2012).

Analisis ragam terhadap skor keracunan besi, baik saat fase vegetatif maupun saat fase generatif tidak berbeda nyata (Tabel 2). Tingkat kemasaman tanah pada pengujian ini tergolong masam ( $\mathrm{pH}$ 4.9). Semua varietas yang diuji masih mampu tumbuh pada kondisi $\mathrm{pH}$ tersebut dan gejala keracunan besi tidak muncul. Fageria et al. (2008) melaporkan bahwa keracunan besi akan muncul pada tanah dengan $\mathrm{pH}$ dibawah 5.8 pada kondisi aerobik dan di bawah pH 6.5 pada kondisi anaerobik. Pada pengujian ini diketahui bahwa meskipun $\mathrm{pH}$ tanah di bawah 5.0, tetapi dengan kondisi tata air yang cukup baik di lokasi pengujian dan pemberian amelioran menyebabkan pertumbuhan tanaman tidak menunjukkan gejala keracunan besi. Kondisi tata air di lokasi pengujian sudah ada saluran pemasukan (inlet) dan pengeluaran (outlet), sehingga air dapat dimasukkan dan dikeluarkan sesuai kebutuhan tanaman.

Varietas Inpara 1 sampai Inpara 9 memiliki umur panen antara 108-113 hari (Tabel 2) dan menunjukkan umur yang lebih pendek 1-18 hari dibandingkan deskripsi varietasnya (BB Padi, 2014). Hal ini biasa terjadi ketika penanaman dilakukan pada musim kering karena pengaruh perbedaan intensitas penyinaran dan jumlah curah hujan. Kurniasih et

Tabel 1. Hasil analisis tanah awal di LRPS, di Desa Karang Bunga, Kabupaten Barito Kuala, MK 2016

\begin{tabular}{lcc}
\hline Sifat kimia tanah & Nilai & Kriteria \\
\hline pH H${ }_{2} \mathrm{O}$ & 4.62 & Masam \\
C-organik $(\%)$ & 5.73 & Sangat tinggi \\
N-total $(\%)$ & 0.46 & Sedang \\
P-Bray $1(\mathrm{ppm} \mathrm{P})$ & 10.83 & Sedang \\
$\mathrm{Ca}-\mathrm{dd}(\mathrm{Cmol}(+) / \mathrm{kg})$ & 1.49 & Sangat rendah \\
$\mathrm{Mg}-\mathrm{dd}(\mathrm{Cmol}(+) / \mathrm{kg})$ & 1.22 & Sedang \\
$\mathrm{K}-\mathrm{dd}(\mathrm{Cmol}(+) / \mathrm{kg})$ & 0.15 & Rendah \\
$\mathrm{Na}-\mathrm{dd}(\mathrm{Cmol}(+) / \mathrm{kg})$ & 0.39 & Rendah \\
$\mathrm{Al}-\mathrm{dd}(\mathrm{Cmol}(+) \mathrm{kg})$ & 4.20 & Rendah \\
$\mathrm{KTK}(\mathrm{Cmol}(+) / \mathrm{kg})$ & 53.40 & Sangat tinggi \\
$\mathrm{Fe}^{2+}(\mathrm{ppm})$ & 439.56 & Tinggi \\
\hline
\end{tabular}


al. (2008) melaporkan bahwa cekaman kekeringan dapat menurunkan pertumbuhan dan hasil serta mempercepat umur berbunga dan panen 5 varietas padi.

Hasil analisis ragam menunjukkan ada variasi tinggi tanaman diantara varietas Inpara pada ketiga fase pengamatan (Tabel 3). Tanaman tertinggi saat panen ditunjukkan oleh varietas Inpara $8(115.3 \mathrm{~cm})$ dan Inpara 9 $(115.6 \mathrm{~cm})$, sedangkan tanaman terendah ditunjukkan oleh varietas Inpara $5(90.1 \mathrm{~cm})$. Tinggi tanaman kedua varietas tersebut (Inpara 8 dan Inpara 9) lebih tinggi dibandingkan deskripsi varietas yang hanya $107 \mathrm{~cm}$ (BB Padi, 2014). Berdasarkan standar IRRI (2014), tinggi tanaman varietas Inpara 1 sampai Inpara 7 tergolong rendah $(<110 \mathrm{~cm})$, sedangkan tinggi tanaman varietas Inpara 8 dan Inpara 9 tergolong sedang $(110-130 \mathrm{~cm})$.

Varietas Inpara 9 memiliki daun dan daun bendera tegak, sehingga malai terlindung dari hama burung. Varietas yang memiliki daun bendera tegak memungkinkan penetrasi dan distribusi cahaya lebih besar sampai ke bagian bawah dan merata, sehingga meningkatkan fotosintesis tanaman. Fotosintesis tanaman dengan kanopi daun tegak sekitar 20\% lebih tinggi dibandingkan kanopi daun terkulai pada kondisi indeks luas daun tinggi (Murchie et al., 2002). Varietas Inpara 9 memiliki kemiripan dengan varietas Margasari. Kelebihan dari varietas tersebut adalah tidak mudah rebah, sedangkan varietas Margasari mudah rebah. Pada pengujian ini, tinggi tanaman varietas Margasari mencapai $125.9 \mathrm{~cm}$ (deskripsi varietas $125-130 \mathrm{~cm}$ ) dan saat panen, hampir $20 \%$ tanaman rebah. Diharapkan dengan adanya kemiripan morfologi tanaman dengan varietas Margasari, varietas Inpara 9 dapat diterima petani di LRPS.

Hasil analisis ragam menunjukkan ada variasi jumlah anakan diantara varietas Inpara pada fase vegetatif dan generatif (Tabel 3). Jumlah anakan varietas Inpara 1 sampai
9 rata-rata sama dengan jumlah anakan ketiga varietas pembanding, kecuali jumlah anakan varietas Inpara 6 lebih rendah daripada jumlah anakan varietas Margasari pada fase vegetatif. Pada fase generatif dan saat panen jumlah anakan per malai varietas Inpara 5 lebih tinggi dibandingkan dengan jumlah anakan per malai varietas Ciherang dan Mekongga, sedangkan varietas Inpara lainnya sama dengan kedua varietas pembanding tersebut.

Hasil analisis ragam terhadap hasil menunjukkan tidak ada beda nyata antar varietas yang diuji (Tabel 4), tetapi dari nilai mutlak hasil tertinggi ditunjukkan oleh varietas Inpara 4 dengan hasil 4.299 ton $\mathrm{ha}^{-1}$. Empat varietas lainnya berproduksi lebih dari 3 ton ha ${ }^{-1}$, yaitu Inpara 3 (3.704 ton ha-1), Inpara 6 (3.829 ton ha-1), Inpara 8 (3.601 ton ha-1), dan Inpara 9 (3.475 ton ha $\left.{ }^{-1}\right)$. Koesrini et al. (2013) juga melaporkan bahwa adaptasi varietas Inpara 3 di LRPS di Kabupaten Barito Kuala cukup baik dengan hasil 3.71 ton ha $^{-1}$. Demikian juga Adri dan Yardha (2014) melaporkan bahwa hasil Inpara 3 di LRPS di Jambi dapat mencapai 6.2 ton $\mathrm{ha}^{-1}$. Adaptasi varietas Inpara 3 juga tergolong baik di lahan rawa lebak di Labuhan Batu Utara, Sumatera Utara dengan hasil 4.25 ton ha $^{-1}$ (Helmi, 2015). Varietas Inpara 3 memiliki adaptasi yang luas, yaitu dapat ditanam di LRPS dan lahan rawa lebak. Varietas yang memiliki adaptasi luas, memiliki nilai interaksi genotipe dan lingkungan yang kecil dan daya hasilnya stabil, sehingga dapat menyesuaikan diri terhadap beberapa lingkungan.

Tabel 4 menunjukkan bahwa ada 5 varietas, yaitu Inpara 3, 4, 6, 8, dan 9 yang berproduksi 38.5-71.3\% lebih tinggi dibandingkan varietas Margasari dan 51.4-87.2\% lebih tinggi dibandingkan varietas Mekongga. Pada saat ini varietas Inpara 3 sudah berkembang, sedangkan varietas Inpara 4, 6, 8, dan 9 belum berkembang. Berdasarkan hasil uji ini, keempat varietas tersebut, memiliki adaptasi

Tabel 2. Skoring pertumbuhan dan keracunan besi saat fase vegetatif dan generatif serta umur panen padi varietas Inpara di LRPS di Desa Karang Bunga, Kabupaten Barito Kuala, MK 2016

\begin{tabular}{|c|c|c|c|c|c|}
\hline \multirow{2}{*}{ Varietas } & \multicolumn{2}{|c|}{ Skor pertumbuhan } & \multicolumn{2}{|c|}{ Keracunan Fe } & \multirow{2}{*}{$\begin{array}{c}\text { Umur panen } \\
\text { (HSS) }\end{array}$} \\
\hline & Vegetatif & Generatif & Vegetatif & Generatif & \\
\hline Inpara 1 & $3.0 \mathrm{a}$ & $2.3 \mathrm{ab}$ & $0.0 \mathrm{a}$ & $2.3 \mathrm{a}$ & 113 \\
\hline Inpara 2 & $2.3 \mathrm{a}$ & $3.0 \mathrm{ab}$ & $0.0 \mathrm{a}$ & $2.0 \mathrm{a}$ & 113 \\
\hline Inpara 3 & $2.3 \mathrm{a}$ & $2.3 \mathrm{ab}$ & $0.0 \mathrm{a}$ & $1.0 \mathrm{a}$ & 113 \\
\hline Inpara 4 & $3.0 \mathrm{a}$ & $1.7 b$ & $0.0 \mathrm{a}$ & $1.7 \mathrm{a}$ & 121 \\
\hline Inpara 5 & $3.0 \mathrm{a}$ & $4.3 \mathrm{a}$ & $0.0 \mathrm{a}$ & $2.3 \mathrm{a}$ & 108 \\
\hline Inpara 6 & $2.3 \mathrm{a}$ & $3.0 \mathrm{ab}$ & $0.0 \mathrm{a}$ & $1.0 \mathrm{a}$ & 108 \\
\hline Inpara 7 & $3.0 \mathrm{a}$ & $2.3 \mathrm{ab}$ & $0.0 \mathrm{a}$ & $1.0 \mathrm{a}$ & 108 \\
\hline Inpara 8 & $2.3 \mathrm{a}$ & $1.7 \mathrm{~b}$ & $0.3 \mathrm{a}$ & $1.0 \mathrm{a}$ & 113 \\
\hline Inpara 9 & $2.3 \mathrm{a}$ & $2.3 \mathrm{ab}$ & $0.0 \mathrm{a}$ & $1.0 \mathrm{a}$ & 113 \\
\hline Ciherang & $3.0 \mathrm{a}$ & $2.3 \mathrm{ab}$ & $0.0 \mathrm{a}$ & $1.7 \mathrm{a}$ & 108 \\
\hline Margasari & $3.0 \mathrm{a}$ & $1.0 \mathrm{~b}$ & $0.0 \mathrm{a}$ & $1.0 \mathrm{a}$ & 113 \\
\hline Mekongga & $3.0 \mathrm{a}$ & $1.7 \mathrm{~b}$ & $0.0 \mathrm{a}$ & $1.7 \mathrm{a}$ & 108 \\
\hline Rataan & 2.7 & 2.3 & 0.1 & 1.5 & 112 \\
\hline
\end{tabular}

Keterangan: Angka yang diikuti huruf beda pada kolom yang sama berbeda nyata pada DMRT taraf 5\% 
Tabel 3. Tinggi tanaman dan jumlah anakan saat fase vegetatif, generatif dan panen padi varietas Inpara di Desa Karang Bunga, Kabupaten Barito Kuala, MK 2016

\begin{tabular}{lcccccc}
\hline & \multicolumn{3}{c}{ Tinggi tanaman $(\mathrm{cm})$} & & & Jumlah \\
\cline { 2 - 7 } Varietas & Vegetatif & Generatif & Panen & $\begin{array}{c}\text { Anakan } \\
\text { maksimum }\end{array}$ & $\begin{array}{c}\text { Anakan } \\
\text { produktif }\end{array}$ & $\begin{array}{c}\text { Malai saat } \\
\text { panen }\end{array}$ \\
\hline Inpara 1 & $52.3 \mathrm{bc}$ & $94.0 \mathrm{~b}$ & $95.6 \mathrm{~d}$ & $17.1 \mathrm{ab}$ & $13.0 \mathrm{bc}$ & $11.6 \mathrm{bc}$ \\
Inpara 2 & $56.5 \mathrm{~b}$ & $97.9 \mathrm{~b}$ & $99.2 \mathrm{c}$ & $16.8 \mathrm{ab}$ & $12.9 \mathrm{bc}$ & $11.8 \mathrm{bc}$ \\
Inpara 3 & $62.0 \mathrm{ab}$ & $94.0 \mathrm{~b}$ & $101.8 \mathrm{c}$ & $14.5 \mathrm{ab}$ & $11.7 \mathrm{bc}$ & $11.3 \mathrm{bc}$ \\
Inpara 4 & $44.1 \mathrm{c}$ & $74.9 \mathrm{c}$ & $94.4 \mathrm{~d}$ & $18.1 \mathrm{ab}$ & $15.9 \mathrm{ab}$ & $14.2 \mathrm{ab}$ \\
Inpara 5 & $48.7 \mathrm{bc}$ & $88.6 \mathrm{bc}$ & $90.1 \mathrm{e}$ & $17.2 \mathrm{ab}$ & $16.5 \mathrm{a}$ & $15.4 \mathrm{a}$ \\
Inpara 6 & $58.9 \mathrm{ab}$ & $101.1 \mathrm{ac}$ & $102.0 \mathrm{c}$ & $13.3 \mathrm{~b}$ & $12.2 \mathrm{bc}$ & $10.9 \mathrm{bc}$ \\
Inpara 7 & $54.5 \mathrm{~b}$ & $97.2 \mathrm{~b}$ & $97.0 \mathrm{~d}$ & $16.9 \mathrm{ab}$ & $13.9 \mathrm{~b}$ & $12.6 \mathrm{bc}$ \\
Inpara 8 & $60.8 \mathrm{ab}$ & $107.6 \mathrm{ab}$ & $115.3 \mathrm{~b}$ & $14.2 \mathrm{ab}$ & $11.1 \mathrm{c}$ & $10.1 \mathrm{c}$ \\
Inpara 9 & $66.8 \mathrm{a}$ & $115.8 \mathrm{a}$ & $115.6 \mathrm{~b}$ & $16.3 \mathrm{ab}$ & $13.4 \mathrm{bc}$ & $14.0 \mathrm{ab}$ \\
Ciherang & $59.3 \mathrm{ab}$ & $98.0 \mathrm{~b}$ & $101.3 \mathrm{c}$ & $15.9 \mathrm{ab}$ & $12.6 \mathrm{bc}$ & $10.6 \mathrm{bc}$ \\
Margasari & $57.9 \mathrm{ab}$ & $117.3 \mathrm{a}$ & $125.9 \mathrm{a}$ & $19.0 \mathrm{a}$ & $15.1 \mathrm{ab}$ & $13.3 \mathrm{ab}$ \\
Mekongga & $50.3 \mathrm{bc}$ & $94.6 \mathrm{~b}$ & $96.2 \mathrm{~d}$ & $16.6 \mathrm{ab}$ & $12.6 \mathrm{bc}$ & $12.8 \mathrm{~b}$ \\
\hline Rataan & 56.1 & 98.4 & 102.9 & 16.3 & 13.4 & 12.4 \\
\hline
\end{tabular}

Keterangan: Angka yang diikuti huruf beda pada kolom yang sama berbeda nyata pada DMRT 5\%

dan kesesuaian serta potensi hasil yang baik dan dapat didiseminasikan ke petani, sebagai varietas alternatif yang dapat dimasukkan ke dalam pola tanam petani di LRPS.

Adaptabilitas varietas dapat dinilai dari hasil dan persen hasil terhadap potensi hasil pada deskripsi atau berdasarkan varietas pembanding. Hasil merupakan resultante dari semua faktor yang mencerminkan pengaruh faktor genetik (varietas) dan lingkungan tumbuh (tanah, air, iklim). Karakter hasil banyak digunakan untuk menilai ketahanan suatu genotipe terhadap kondisi biofisik lahan. Berdasarkan hasil terdapat lima varietas yang berproduksi lebih dari 3 ton $\mathrm{ha}^{-1}$, dan berproduksi lebih $50 \%$ dari potensi hasil (Tabel 4).

Keragaan hasil pada pengujian ini belum sepenuhnya mencapai potensi hasil seperti deskripsi varietas. Hal ini disebabkan kondisi lahan yang masih belum optimal $(\mathrm{pH}$

Tabel 4. Hasil dan potensi hasil padi varietas yang diuji di Desa Karang Bunga, Kecamatan Mandastana, Kabupaten Barito Kuala, MK 2016

\begin{tabular}{|c|c|c|c|c|c|c|}
\hline Varietas & $\begin{array}{c}\text { Hasil } \\
\left(\text { ton } \mathrm{ha}^{-1}\right)\end{array}$ & $\begin{array}{l}\text { Potensi hasil } \\
\left(\text { ton } \mathrm{ha}^{-1}\right)^{*}\end{array}$ & $\begin{array}{c}\% \text { hasil terhadap } \\
\text { potensi hasil }\end{array}$ & $\begin{array}{c}\text { PH terhadap } \\
\text { Margasari (\%) }\end{array}$ & $\begin{array}{l}\text { PH terhadap } \\
\text { Ciherang }(\%)\end{array}$ & $\begin{array}{c}\text { PH hasil terhadap } \\
\text { Mekongga }(\%)\end{array}$ \\
\hline Inpara 1 & $2.54 \mathrm{a}$ & 6.47 & 39.22 & 1.11 & -24.76 & 10.54 \\
\hline Inpara 2 & $2.73 a$ & 6.08 & 44.84 & 8.61 & -19.82 & 18.73 \\
\hline Inpara 3 & $3.70 \mathrm{a}$ & 5.60 & 66.14 & 47.57 & 9.81 & 61.32 \\
\hline Inpara 4 & $4.30 \mathrm{a}$ & 7.60 & 56.57 & 71.27 & 27.46 & 87.24 \\
\hline Inpara 5 & $2.34 \mathrm{a}$ & 7.20 & 32.46 & -6.89 & -30.71 & 1.79 \\
\hline Inpara 6 & $3.83 \mathrm{a}$ & 6.00 & 63.82 & 52.54 & -13.59 & 66.77 \\
\hline Inpara 7 & $2.40 \mathrm{a}$ & 5.10 & 46.96 & -4.58 & -28.99 & 4.31 \\
\hline Inpara 8 & $3.60 \mathrm{a}$ & 6.00 & 60.02 & 43.47 & 6.76 & 56.84 \\
\hline Inpara 9 & $3.48 \mathrm{a}$ & 5.60 & 62.05 & 38.45 & 3.02 & 51.35 \\
\hline Ciherang & $3.37 \mathrm{a}$ & 7.00 & 48.19 & 34.38 & - & 46.91 \\
\hline Margasari & $2.51 \mathrm{a}$ & 4.50 & 55.78 & - & -25.59 & 9.32 \\
\hline Mekongga & $2.30 \mathrm{a}$ & 6.00 & 38.26 & -8.52 & -31.93 & - \\
\hline Rataan & 3.09 & 6.10 & 51.19 & 25.22 & -11.67 & 37.74 \\
\hline
\end{tabular}

Keterangan: Angka yang diikuti huruf sama pada kolom yang sama tidak berbeda nyata pada DMRT 5\%, PH=peningkatan/penurunan hasil Tanda *: berdasarkan deskripsi varietas (BB Padi, 2014) 
masih masam, kandungan besi $169.02 \mathrm{ppm}$ dan $\mathrm{pH}$ air masih sangat masam $(<4.5)$ ). Audebert dan Sahrawat (2000) melaporkan bahwa terdapat korelasi negatif antara hasil dan skor keracunan besi pada daun. Semakin tinggi keracunan besi, hasil semakin rendah. Kultivar padi yang toleran keracunan besi menyerap lebih sedikit besi atau sedikit mentranslokasi besi dari akar ke daun yang mengindikasikan adanya mekanisme avoidance. Laju fotosintesis bersih pada kultivar rentan lebih rendah daripada kultivar toleran. Mehraban et al. (2008) melaporkan bahwa pembentukan total klorofil menurun pada kondisi keracunan besi. Terhambatnya pembentukan klorofil, menyebabkan laju fotosintesis menjadi rendah dan hasil tanaman menjadi rendah. Wahyuti et al. (2013) melaporkan bahwa terdapat korelasi positip antara kandungan klorofil daun dan hasil tanaman padi.

Pengembangan padi ke LRPS memerlukan varietas yang adaptif terhadap cekaman lingkungan terutama kemasaman tanah, keracunan besi, dan cekaman air. Tanaman yang toleran terhadap cekaman lingkungan mempunyai kemampuan untuk beradaptasi secara morfologi dan fisiologi, sehingga tanaman dapat tumbuh dan berproduksi optimum.

\section{KESIMPULAN}

Hasil uji adaptasi varietas Inpara menunjukkan ada perbedaan adaptasi varietas Inpara di LRPS. Berdasarkan hasil terdapat 5 varietas yang berproduksi lebih dari 3 ton $\mathrm{ha}^{-1}$ dan memiliki adaptasi serta kesesuaian dengan LRPS. Kelima varietas tersebut adalah Inpara 3, 4, 6, 8, dan 9 dengan hasil masing-masing 3.704 ton $\mathrm{ha}^{-1}, 4.299$ ton ha-1, 3.830 ton $\mathrm{ha}^{-1}, 3.602$ ton ha- ${ }^{-1}$, dan 3.475 ton ha- ${ }^{-1}$ Kelima varietas tersebut berproduksi $38.5-71.3 \%$ lebih tinggi dibandingkan varietas Margasari dan 51.4-87.2\% lebih tinggi dibandingkan varietas Mekongga.

\section{DAFTAR PUSTAKA}

Adri, Yardha. 2014. Upaya peningkatan produktivitas padi melalui varietas unggul baru mendukung swasembada berkelanjutan di Provinsi Jambi. J. Agroekotek 6:111.

Audebert, A., K.L. Sahrawat. 2000. Mechanisms for iron toxicity tolerance in lowland rice. J. Plant Nutr. 23:1877-1885.

Balittra. 2016. Data pencatatan AWS di KP Belandean, Kabupaten Barito Kuala. Balai Penelitian Pertanian Lahan Rawa.

[BB Padi] Balai Besar Penelitian Tanaman Padi. 2014. Deskripsi varietas. http://bbpadi.litbang.pertanian. go.id [28 September 2016].
Statiun Klimatologi Banjarbaru. 2016. Buletin BMKG volume 4-8, edisi April sampai Agustus 2016.

Debrata, P., R.K. Sarker. 2012. Role of non structural carbohydrate and its catabolism associated with sub 1 QTL in rice subjected to complete submergence. Exp. Agric. 48:502-512.

Fageria N.K., A.B. Santos, M.P.B. Filho, C.M. Guimaraes. 2008. Iron toxicity in lowland rice. J. Plant Nutr. 31:1676-1697.

Hairmansis, A., Supartopo, B. Kustianto, Suwarno, H. Pane. 2012. Perakitan dan pengembangan varietas unggul baru padi toleran rendaman air Inpara 4 dan Inpara 5 untuk daerah rawan banjir. J. Penelitian Pengembangan Pertanian 31:1-7.

Helmi. 2015. Peningkatan produktivitas padi lahan rawa lebak melalui penggunaan varietas unggul padi rawa. J. Pertanian Tropik 2:78-92.

[IRRI] International Rice Research Institute. 2014. Standar Evaluation System for Rice. IRRI, Manila, Philippines.

Isdijanto, A., M. Alwi, Nurita. 2015. Peningkatan hasil padi di tanah sulfat masam melalui kombinasi perlakuan pelindian dan olah tanah. J. Agron. Indonesia 43:105110 .

Koesrini, M. Saleh, D. Nursyamsi. 2013. Keragaan varietas Inpara di lahan rawa pasang surut. Pangan 22:221227.

Kurniasih, Taryono, Toekidjo. 2008. Keragaan beberapa varietas padi (Oryza spp.) pada kondisi cekaman kekeringan dan salinitas. Ilmu Pertanian 15:49-58.

Kustianto, B. 2009. Produktivitas galur harapan padi di lahan pasang surut dan lahan rawa lebak. J. Penelitian Pertanian Tanaman Pangan 28:34-38.

Majerus V, P. Bertin, S. Lutts. 2007. Effect of iron toxicity on osmotic potential, osmolytes and polyamines concentrations in the African rice (Oryza glaberrima Steud.). Plant Sci. 173:96-105.

Mehraban, P., A.A. Zadeh, H.R. Sadeghipour. 2008. Iron toxicity in rice (Oryza sativa L.) under different potassium nutrition. Asian J. Plant Sci. 7:251-259.

Murchie, E.H., J. Yang, S. Hubbart, P.Horton, S. Peng. 2002. Are there association between grain-filling rate and photosynthesis in the flag leaves of field-grown rice. J. Exp. Bot. 53:2217-2224. 
Nursyamsi, D., M. Noor. 2014. Prospek dan strategi pengembangan padi rawa pasang surut. hal.1-21. Dalam D. Nursyamsi, M. Noor, I. Khairullah, E. Husein, H. Subagio, S. Sabiham, F. Agus, I. Las (Eds). Teknologi Inovasi Lahan Rawa Pasang Surut Mendukung Kedaulatan Pangan Nasional. IAARD Press, Jakarta, Indonesia.

Rina, Y., Koesrini. 2016. Tingkat adopsi varietas Inpara dan Margasari di lahan rawa pasang surut. Agros 18:6580 .
Virmani, S.S. 1977. Varietal tolerance of rice to iron toxicity in Liberia. Internat. Rice Res. News 2:4-5.

Wahyuti, T.B., B.S. Purwoko, A. Junaedi, Sugiyanta, B. Abdullah. 2013. Hubungan karakter daun dengan hasil padi varietas unggul. J. Agron. Indonesia 41:181-187. 